\title{
Human Capital, Its Constituents, and Entrepreneurial Innovation: A Multi-Level Modelling of Global Entrepreneurship Monitor Data
}

\author{
Vijay Vyas and Renuka Vyas
}

\author{
" ") \\ Innovation has nothing to do with how \\ many $R \& D$ dollars you have... It's not \\ about money. It's about the people you \\ have.
}

Steve Jobs (1955-2011), Co-founder of Apple and Pixar

\begin{abstract}
In this study, we use multi-level modelling to analyze data of over 200,000 businesses in 96 countries to explain the failure of previous research to extend human capital theory to innovation. We trace this failure to, previously overlooked, conflicting influences of education and experience. The two key constituents of human capital are often used in research as innovation antecedents and present a conceptual and empirical case against the use of work experience as a constituent of human capital. Our hierarchical exploration of innovation antecedents shows that, at the individual level, being young and recently educated are significant predictors of innovation whereas, at the societal level, national wealth dampens the negative effect of age on innovation and accentuates the positive effect of education on it.
\end{abstract}

\section{Introduction}

Recently, the role of human capital in entrepreneurship has attracted substantial scholarly interest (Dimov, 2017; Dutta \& Sobel, 2018; Marvel et al., 2016; Unger et al., 2011). Within the resulting literature, studies on the link between human capital and innovation have yielded counterintuitive and conflicting results (Wincent et al., 2010). Subramaniam and Youndt (2005), for instance, report that human capital is adversely related to radical innovation capability, Marvel and Lumpkin (2007) find that market knowledge is negatively influences radical innovation, and Delgado-Verde and co-authors (2016) do not find support for their proposed inverted $U$-shaped positive effect of human capital on radical innovation. At the same time, many studies examining this relationship report a positive link (e.g., Colombo et al., 2017; Crespo \& Crespo, 2016; Kianto et al., 2017; Miguélez et al., 2011; Rupietta \& Backes-Gellner, 2017).

Teixeira and Fortuna (2010) argue that, "human capital is generally poorly proxied, and measurement problems are particularly acute when it comes to this variable". We advance this argument further and clarify the cause of the conflicting findings described above. We find that education, experience, or both are often used as the building blocks of human capital and the empirical research has frequently measured the outcome of the impact of education or experience or education plus experience on innovation. However, as we show below, experience and education leverage innovation in opposite directions, therefore when the relationship between human capital and innovation is empirically tested, the outcomes turn out to be divergent. More specifically, as Table 1 shows, when human capital is articulated purely in terms of educational attainment or where experience is excluded from the calculus of its measurement, the effect of human capital on innovation is invariably positive. In contrast, when human capital is measured purely in experience terms or when experience is a part of its calculus, an analysis of its influence on innovation often yields a negative or non-significant relationship.

\section{Work experience as human capital: The conceptual incongruity}

Ostrom and Ahn (2009), observe that "All forms of capital involve the creation of assets by allocating resources that could be used up in immediate consumption to create assets that generate a potential 


\section{Human Capital, Its Constituents, and Entrepreneurial Innovation}

\section{Vijay Vyas and Renuka Vyas}

flow of benefits over a future time horizon." The creation of human capital, too, thus involves diverting resources from current consumption and investing them to generate a potential flow of future benefits. This happens when people invest in education, training, or health or when they allot time and money to migrate to places where they hope to have better incomes and lives. All of these actions, therefore, give rise to human capital. However, when people take up employment and begin to accumulate work experience, they do it primarily to earn immediate benefits. This is a key difference between education and work experience, two potential enhancers of human productivity. People seek education principally for future economic benefits whereas they seek employment primarily for current benefits. Further, investment entails diversion of

Table 1. Performance influence of human capital

Source HumanCapital Performance Measures Selected Relevant Results
Const ituents

Subramaniam \& Youndt Knowledge, skills, Radical innovation capability Negative effect

(2005) and ability (KSA)

Marvel \& Lumpkin (2007) Education, breadth Innovation radicalness

Strong effect of education, we ak effect and length of of length of experience, no effect of experience breadth of experience

Rodríguez-Pose \& $\quad$ Education Re gional innovation esitive effect

Crescenzi (2008)

Teixeira \& Fortuna (2010) Education Total factor productivity Subs tantial positive effect

Wincent et al. (2010) Board's education Innovative performance of Positive effect

and diversity ne twork participants

Al-Laham et al. (2011) Education and Patents renewal Education has positive and tenure has tenure negative effect

\begin{tabular}{|c|c|c|c|}
\hline$\underline{\text { Miguelez et al. (2011) }}$ & Education & Number of patents & Positive effe ct \\
\hline Robson, et al. (2012) & $\begin{array}{l}\text { Education and } \\
\text { experience }\end{array}$ & $\begin{array}{l}\text { Engagement in innovation } \\
\text { activities }\end{array}$ & $\begin{array}{l}\text { Experience strong po sitive effect, } \\
\text { education weak effe ct }\end{array}$ \\
\hline $\begin{array}{l}\text { Castellacci \& Natera } \\
(2013)\end{array}$ & Education & $\begin{array}{l}\text { Innovation dynamics (ID): per } \\
\text { capita growth (PCG) }\end{array}$ & $\begin{array}{l}\text { Positive effe ct of secondary education } \\
\text { on ID and of tertiary education on PCG }\end{array}$ \\
\hline $\begin{array}{l}\text { Belso-Martinez et al. } \\
\underline{(2013)}\end{array}$ & $\begin{array}{l}\text { Education, research } \\
\text { experience }\end{array}$ & $\begin{array}{l}\text { Performance of new } \\
\text { innovative firm }\end{array}$ & No effe ct \\
\hline Felsenstein (2015) & Education & Re gional innovation & Large positive effect \\
\hline McGuirk et al. (2015) & $\begin{array}{l}\text { Education, training, } \\
\text { and othe rs }\end{array}$ & $\begin{array}{l}\text { Product, process, and service } \\
\text { innovation }\end{array}$ & Positive effe ct of training \\
\hline $\begin{array}{l}\text { Delgado-Verde et al. } \\
(2016)\end{array}$ & KSA & Radical innovation & $\begin{array}{l}\text { Inverted U-shaped positive effect not } \\
\text { supported }\end{array}$ \\
\hline Crespo \& Crespo (2016) & Education & $\begin{array}{l}\text { Knowledge, technology, and } \\
\text { creative outputs }\end{array}$ & Positive effe ct \\
\hline $\begin{array}{l}\text { Rupie tta \& Backes - } \\
\text { Gellner (2017) }\end{array}$ & Education & Incremental innovation & $\begin{array}{l}\text { Human capital a key component of } \\
\text { innovation affecting configuration }\end{array}$ \\
\hline Colombo et al. (2017) & Education & R\&D investments & Positive effe ct \\
\hline
\end{tabular}




\section{Human Capital, Its Constituents, and Entrepreneurial Innovation}

\section{Vijay Vyas and Renuka Vyas}

resources from current consumption for future potential benefits. This happens with education but not with employment. Employment, therefore, is not investment and the work experience that it provides is not human capital. Finally, as Becker (1964) suggests, "forgone earnings are an important, although neglected cost of much investment in human capital". Forgone earnings are obvious in education. However, usually there are no forgone earnings in the process of gaining work experience. We argue that, unless we are able to trace the origin of a productive human advantage to some form of investment of resources diverted from current consumption or to some forgone earnings, what we have is not human capital. It is therefore conceptually wrong to consider work experience a constituent of human capital.

In this article, we first provide a review of literature on human capital underscoring the contribution of key pioneers of this concept. We then present our primary as well as moderating hypotheses and the conceptual and empirical logic underpinning them. Data and measures used in this work are then elaborated and variables are specified. This is followed by our rationale for using multi-level modelling as well as the details of the data analysis process. Finally, we discuss our results, highlight our contribution and spell out the limitations of this work, its future research directions, as well as its policy implications.

\section{Literature Review: Human Capital}

Though traces of human capital doctrine could be seen in Adam Smith's writing as early as 1776 (Smith, 1952), it was not until the 1960s that human capital emerged as an influential contribution to enhancements in human productivity in the economic growth process. Becker's (1964) definition of human capital, as "the knowledge, information, ideas, skills, and health of individuals" (Becker, 2002) is, essentially, not much different from its modern perception as "the characteristics possessed by... individual(s) that can yield positive outcomes for (them)" (Wright \& McMahan, 2011).

Schultz and Becker contributed most to the early articulation of human capital doctrine and in estimating its contribution in the calculus of economic growth. Its basic premise was that individuals accumulate productive human capital over time by way of knowledge, skills, and expertise and investments in human capital, particularly in education, account for a significant part of economic growth (Becker, 1962, 1964; Schultz, 1960, 1961). Pioneering work on the role of human capital in economic growth was duly rewarded. Starting with Schultz and Becker, five Nobel prizes in economic sciences were awarded to scholars for their contributions in this field, with the other three going to Milton Friedman, Simon Kuznets, and Robert Solow (Sweetland, 1996).

Despite wide acceptance of the value of human capital construct in explaining economic growth, the analyst who pioneered the concept diverged on what were its precise building blocks, something which remains unchanged until now, as we have shown above. Schultz's (1961) configuration included health services, on-the-job training, education, and migration, whereas Becker (1964) included education, on the job training, information, and health. Contrary to the impression in some of the recent literature (e.g., Cao \& Im, 2018; Davidsson \& Honig, 2003; Marvel \& Lumpkin, 2007), Becker $(1962,1964)$ did not include work experience as a component of human capital in his analysis (and, as stated above, neither did Schultz [1960, 1961]. Among the pioneers, Mincer (1974) was conspicuous for his inclusion of work experience as a component of human capital and, in all likelihood, was responsible for a tradition of its inclusion in it that continues until today.

We believe that, to unpick the contribution of human capital's various candidate elements in the innovation process, it is imperative that we decompose it into its key postulated constituents to better understand their individual roles in entrepreneurial innovation. Using age as a proxy for experience, we have attempted it here.

\section{Hypothesis Development}

\section{Education and innovation}

At the start of 20th century, formal education gradually began to be seen as a vital influence on innovation (Nelson \& Rosenberg, 1993), and this continues to be the case. Holbrook and Clayman (2003) report that tertiary education develops the innovative skills of recipients. Leiponen (2005) shows that high educational levels complement product and process innovation. Vila and co-authors (2012) report that learning and teaching modes used in higher education develop innovation competencies. Investments in education explain a significant part of rise in total factor productivity in Portugal (Teixeira \& Fortuna, 2010) as well as across the European Union (Bonin, 2017). Crespo and Crespo (2016) show that a high "level and standard of education" is linked with high innovation performance. Colombo and co-authors (2017) report that the share of employees with at least a university degree in the workforce is a significant predictor of $R \& D$-to-Sales 


\section{Human Capital, Its Constituents, and Entrepreneurial Innovation}

\section{Vijay Vyas and Renuka Vyas}

ratio. Given the evidence on the nexus between education and innovation in such a range of milieus (Arvanitis \& Stucki, 2012), we argue that the premise that an entrepreneurs' education would positively influence innovation in their enterprises follows logically and naturally.

We thus hypothesize that:

Hypothesis 1: Entrepreneur education positively influences innovation in their enterprises.

\section{Age and innovation}

The balance of evidence on the relationship between age and innovation decisively points to a negative connection. Pfeifer and Wagner (2012) record a strong adverse impact of average age on several innovationlinked indicators. Schubert and Andersson (2015) find the age of an individual to be negatively related to their innovation performance, and Arntz and Gregory (2014) show that $17 \%$ of the gap in regional innovation performance in Germany is explained by demographic aging. In a related context, Jones (2010) reports scientists' peak creative productivity in middle age, which is followed by declining performance. We found only one study (Ng \& Feldman, 2013a) that positively links age with innovation-related behaviour. However, the same authors did not find such a relationship an earlier study (Ng \& Feldman, 2008) or in their metaanalysis (Ng \& Feldman, 2013b). These findings indicate that the evidence for a positive relationship is limited and sketchy. Furthermore, it is shown that the innovative advantage of the young lies in their higher risk tolerance (Lévesque \& Minniti, 2006) and in the contemporariness of their technological skills (Ouimet \& Zarutskie, 2011).

We thus hypothesize that:

Hypothesis 2: Entrepreneur age is negatively linked with innovation in their enterprises.

\section{National income and innovation}

Despite the widely recognized causal nexus of innovation with competitiveness, growth, and economic prosperity, the potential inverse causation between current levels of national income and future innovation has not been theoretically discussed or empirically tested. We argue that the nature and direction of causality here can be deduced from the findings of works on the relationship of current levels of per capita income with future prospects of growth. Barro's (1991) finding that "higher per capita GDP is substantially negatively related to subsequent per capita (income) growth" and his more recent estimate of "conditional convergence rate around $2 \%$ per year" (Barro, 2015) indicate that highly innovative nations are likely to have slower future increases in their innovativeness. This result is also inferred from Kortum's (1997) search model, which shows that technological advances push a nation closer to the technological frontier and decrease the technological gap, ceteris paribus, diminishing its future innovation potential. Conversely, from the convergence literature, Gerschenkron's (1952) conception of "advantage of backwardness" implies that further a country stands behind the technology frontier, larger it has the scope for innovation.

We thus hypothesize that:

Hypothesis 3: Per capita income of a country is negatively related to innovation in its enterprises.

Next, we consider moderating hypotheses.

\section{Effect of age on the relationship between education and innovation}

We argue that the ability of entrepreneurs to utilize their formal education for innovation will diminish with age on the premise that the general decline in the value of knowledge with time (Frosch \& Tivig, 2007) applies to its value for innovation as well. Innovation involves the creation of new products, processes, and forms of organizations that perform better than the existing ones. We argue that the entrepreneurs' ability to innovate depends on the contemporariness of their knowledge. Up-to-date knowledge related to products, processes, and organizations is a prerequisite to conceptualize, create, and use their future and better versions. The earlier the acquisition of knowledge is, the more primeval the products, processes, and organizations are that it relates to. Frosch and Tivig (2007) find that, "engineering knowledge and, to a smaller extent, formal academic knowledge lose their innovation-enhancing effect when the labor force grows older". Further, as Simonton's (1988) work shows, the "ideations' ability the knack to visualise a new realm of possibility by recombining knowledge - diminishes with age as the fluid intelligence falls (Kanfer \& Ackerman, 2004), leading to a reduced ability of an entrepreneur to take advantage of their knowledge for innovation.

We thus hypothesize that:

Hypothesis 2a: Entrepreneur age negatively moderates the effect of education on innovation in their enterprises. 


\section{Human Capital, Its Constituents, and Entrepreneurial Innovation}

\section{Vijay Vyas and Renuka Vyas}

\section{Effect of national wealth on relationships of age and} education with innovation

Entrepreneurs' efforts to utilize their education and age-related competencies for innovation could be supported or hindered by the environments within which they operate. The national system of innovation perspective posits that, in relation to the ability of an individual to innovate, the role of "the national education system, industrial relations, technical and scientific institutions, government policies, cultural traditions and many other national institutions is fundamental" (Freeman, 1995). Innovation-enabling overarching national characteristics include the quality and extensiveness of higher education (Lundvall, 2008), the calibre of public and private research institutions (Albuquerque et al., 2015), and the value national governments place on innovation as well as their ability and preparedness to support it (Watkins et al., 2015). The potential of these innovation-enabling influences is closely connected to the levels of national wealth. Countries with high per capita income have, in general, better universities and research organizations as well as more transparent, efficient, and effective governments. As a result, other things being equal, entrepreneurs engaging in innovation in affluent countries find themselves operating in more enabling environments. They are thus able to use their education for innovation more successfully than entrepreneurs are in poorer countries. The superiority of innovationenabling environments in wealthier countries also weakens the negative effect of age on an entrepreneurs' ability to innovate.

We thus hypothesize that:

Hypotheses 3a: Per capita national income positively moderates the effect of education on innovation.

Hypotheses 3b: Per capita national income negatively moderates the effect of age on innovation.

\section{Data and Measurements}

\section{Data}

The gross national income per capita (GNI) data for this work is taken from the Human Development Index (UNDP, 2014). The rest of the data comes from Global Entrepreneurship Monitor's (GEM) Adult Population Surveys (APS) from 2005 to 2011 in 96 countries

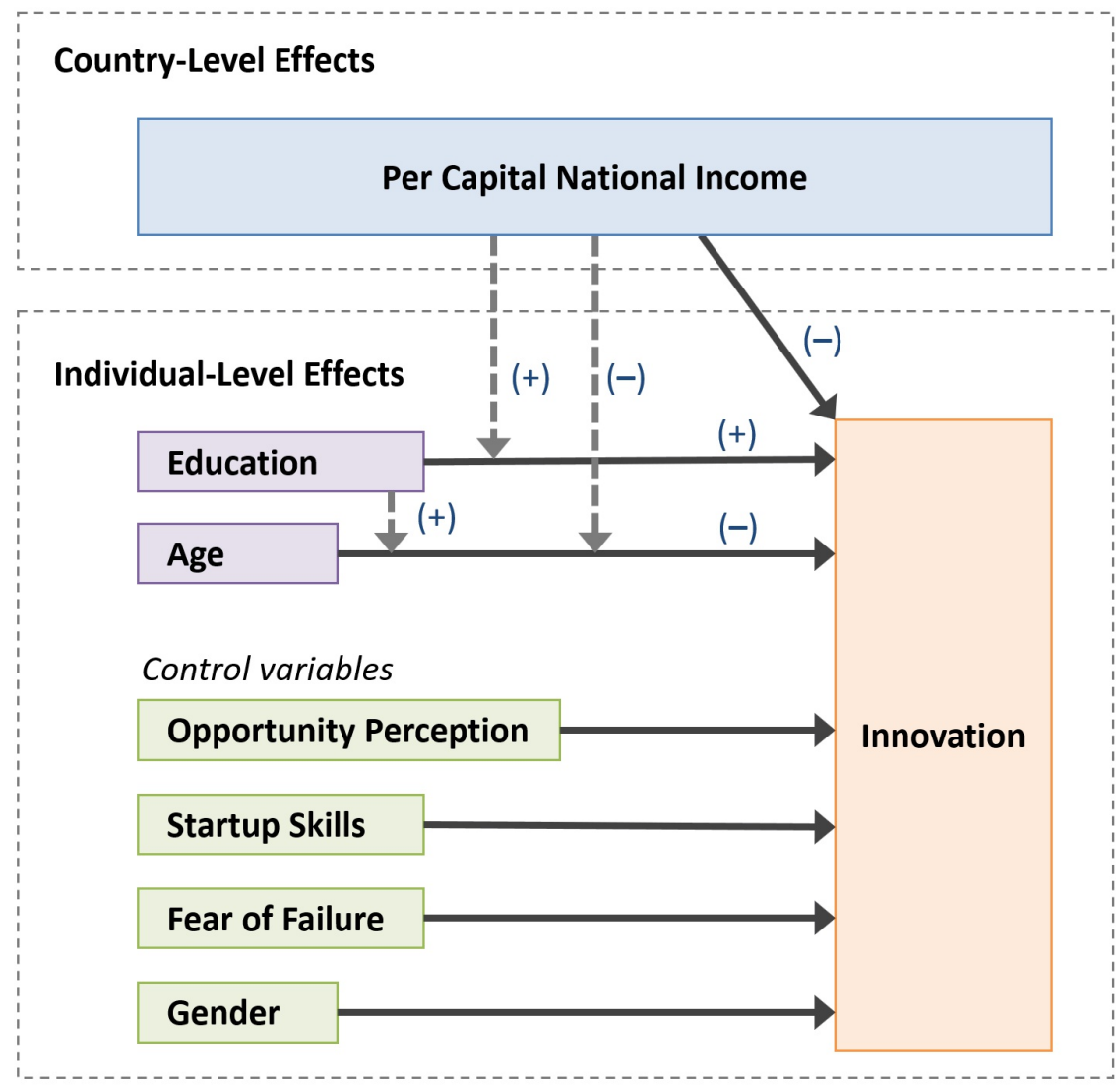

Figure 1. Conceptual model 


\section{Human Capital, Its Constituents, and Entrepreneurial Innovation}

\section{Vijay Vyas and Renuka Vyas}

(Reynolds et al., 2005). GEM data is well recognized for its quality, and its use has made significant contribution to entrepreneurship research over many years (Levie et al., 2014). For the APS, a minimum of 2,000 randomly chosen adults are interviewed in each participating country in a survey commissioned by GEM's respective country teams. All consequent data is weighted by relevant demographic variables to harmonize it and make it as representative as possible of the respective countries' adult populations (Reynolds et al., 2005 provide a detailed explanation of the GEM method). The APS data constitutes a fairly representative sample of adults in surveyed countries. From this sample, 210,554 owner-managers of existing businesses are sub-sampled for analysis here. The findings are therefore generalizable to the universe of all firms in these countries (Schøtt \& Jensen, 2016).

The GEM model generates multi-level data (Levie \& Autio, 2008), which can be used to draw meaningful inferences only through multi-level modelling (Carson \& Beeson, 2013), as we have attempted here.

\section{Dependent variable}

Innovation is measured from the data generated by the answers to three APS questions given below:

1. "Will all, some, or none of your potential customers consider this product or service new and unfamiliar?" The useable answers and related original data values (in parenthesis), vary between, all (1), some (2), and none (3).

2. "Right now, are there many, few, or no other businesses offering the same products or services to your potential customers?" The useable answers and related original data values (in parenthesis), vary between, many business competitors (1), few business competitors (2), and no business competitors (3).

3. "Have the technologies or procedures required for this product or service been available for less than a year, or between one to five years?" The useable answers and related original data values (in parenthesis), vary between less than a year (1), between one to five years (2), and longer than five years (3).

For questions 1 and 3 above, higher data values imply lower innovation. The data reversal is therefore applied to generate the data sets with higher values implying higher innovation. After confirming statistically significant positive correlations among the data sets, with two of them so modified, a new variable "Innovation" is created by adding the mean of data values for three innovation-related questions. This means that the innovation so measured covers product as well as process innovation but excludes organizational innovation.

\section{Independent variables}

Entrepreneur age is self-reported chronological age. It varies between 18 years to 64 years in APS data.

Entrepreneur education is self-reported years of formal education. It varies between 0 to 19 years in our data.

GNI is Gross national income per capita (in 2011) taken from Human Development Index (UNDP, 2014). It is expressed in thousands of Purchasing Power Parity dollars and varies between 0.715 for Malawi and 72.371

Table 2. Correlations and descriptive statistics

\begin{tabular}{|c|c|c|c|c|c|c|c|}
\hline \multicolumn{8}{|l|}{ Correlations } \\
\hline & Opport & Nofearfail & Gender & Age & Education & GNI & INNO \\
\hline Opport & 1 & & & & & & \\
\hline Suskill & $.139^{-}$ & & & & & & \\
\hline Nofe arfail & $.111^{-}$ & 1 & & & & & \\
\hline Gender & .002 & $.040^{*}$ & 1 & & & & \\
\hline Age & $-.129^{-}$ & $-.018^{-}$ & $.024^{-}$ & 1 & & & \\
\hline Education & $-.040^{-}$ & $.036^{* *}$ & $.055^{-}$ & $-.007^{-}$ & 1 & & \\
\hline $\mathrm{GNI}$ & $-.153^{-}$ & $.019^{*}$ & $.065^{-}$ & $.228^{*}$ & $.368^{-}$ & 1 & \\
\hline INNO & $.081^{-}$ & $.025^{* *}$ & $-.010^{* *}$ & $-.102^{-}$ & $.079^{-}$ & $-.039^{-}$ & 1 \\
\hline \multicolumn{8}{|c|}{ Descriptive Statistics } \\
\hline Mean & .57 & .74 & .61 & 40.12 & 11.58 & 21.77 & 1.48 \\
\hline Std. Deviation & .50 & .44 & .49 & 11.65 & 4.63 & 14.6 & .47 \\
\hline $\mathrm{N}$ & 185106 & 204027 & 210514 & 210554 & 205883 & 210431 & 210554 \\
\hline
\end{tabular}

:* Correlation is significant at the 0.01 level (2-taile d) 


\section{Human Capital, Its Constituents, and Entrepreneurial Innovation}

\section{Vijay Vyas and Renuka Vyas}

\section{for Singapore.}

\section{Control variables}

We have used four control variables for our analysis. A prerequisite for innovation is that the innovator is 'not constrained by a fear of failure' (Amabile \& Khaire, 2008). We therefore expect fear of failure to be negatively related to innovation. By reversing the Fearfail variable in GEM data, we have recorded it as Nofearfail with 0 if answer is "yes" and 1 if it is "no" to the APS question "Fear of failure would prevent you from starting a business." As ability to spot opportunities is at the core of innovation (Gailly, 2018), we have included, as a control variable, Opport from the APS, which is a measure of entrepreneur's ability to "perceive good business opportunities". The APS variable Suskill, which measures an entrepreneur's knowledge and skills in starting a business, is our third control variable. We have chosen it based on the argument that knowledge and skills needed to start a new business would also be useful in introducing a new product, new service, or a new way of doing business. Though Gender as an innovation influence continues to be under-researched, particularly within entrepreneurship literature, it is now increasingly recognized as an important influence on innovation (Alsos, et al. 2012); we have therefore included it as our fourth control variable.

\section{Random effects variable}

In our multi-level model (MLM), we have used Country, in GEM data, as the random effects variable.

\section{Correlations matrix and descriptive statistics}

The correlations, means, and standard deviations of the variables involved in this nalysis are given in Table 2 . Correlations of all control variables with innovation are statistically significant. All three hypothesized independent variables are also significantly correlated with innovation at $\mathrm{P}<0.01$, and the directions of correlations are as postulated. However, no set of independent variables are highly correlated (Pearson correlation coefficient $>0.5$ ). This finding rules out multicollinearity. These results also show that entrepreneurs from wealthier countries are older and more educated. However, they are less innovative, indicating a more powerful combined negative influence of age and national wealth on innovation than that of education. They also reveal that the younger entrepreneurs are more educated and are more innovative. One noteworthy finding from this analysis is that, globally, woman entrepreneurs are marginally more innovative than men, and this difference is statistically significant.

\section{Data Analysis and Results}

We deploy MLM to examine the influence of entrepreneur age, education, and per capita national income of their countries on innovation with random effects of their national location through the variable Country.

\section{Random effects model}

After generating the Null model with baseline values, we first test if the variable Country has valid random effects within MLM estimation procedure. The following equation for this model postulates that observed Innovation (I) is explained by the general intercept $\left(\gamma_{0}\right)$, the random effects of Country $\left(\mu_{\mathrm{c}}\right)$ and by a random error (or unexplained variance) $(\varepsilon)$ :

$\mathrm{I}=\gamma_{0}+\mu_{\mathrm{c}}+\varepsilon$

The results of this model are summarized in Table 3, Model 2, which show that random effects of country $\left(\mu_{c}\right)$ are highly significant are highly significant $(\mathrm{p}<$ 0.001), indicating, as postulated, that observed innovation varies across countries. The variable Country, therefore, can be justifiably included in the predictor model as random effects.

\section{MLM with controls}

We now use MLM to test if opportunity perception, start-up skills, no fear of failure, and gender are valid influences on innovation to be used as control variables. Level 1 (individual level) variables such as these control variables as well as the predictors with a raw metric with no meaningful zero point must be centred to have correct interpretation of results in multi-level modelling (Enders \& Tofighi, 2007). As our focus is on an individual-level variable, entrepreneurial innovation, we need to deploy grand mean centring for this purpose (Carson \& Beeson, 2013). We use this to centre control variables as well as to centre all predictors subsequently.

The MLM equation at this stage postulates that, in addition to the general intercept $\left(\gamma_{0}\right)$, the random effect of country $\left(\mu_{\mathrm{c}}\right)$ and the random error $(\varepsilon)$, opportunity perception $\left(\gamma_{\text {opport }}\right)$, start-up skills $\left(\gamma_{\text {suskil }}\right)$, no fear of failure $\left(\gamma_{\text {nff }}\right)$ and gender $\left(\gamma_{\text {gender }}\right)$ explain the observed innovation further.

$\mathrm{I}=\gamma_{0}+\gamma_{\text {opport }}+\gamma_{\text {suskil }}+\gamma_{\text {nff }}+\gamma_{\text {gender }}+\mu_{\mathrm{c}}+\varepsilon$

The results of this model, summarized in Table 3, reveal fixed effects of all control variable as well as random effects of variable Country to be highly significant ( $p<$ $0.001)$. 


\section{Human Capital, Its Constituents, and Entrepreneurial Innovation}

Vijay Vyas and Renuka Vyas

Table 3. Results

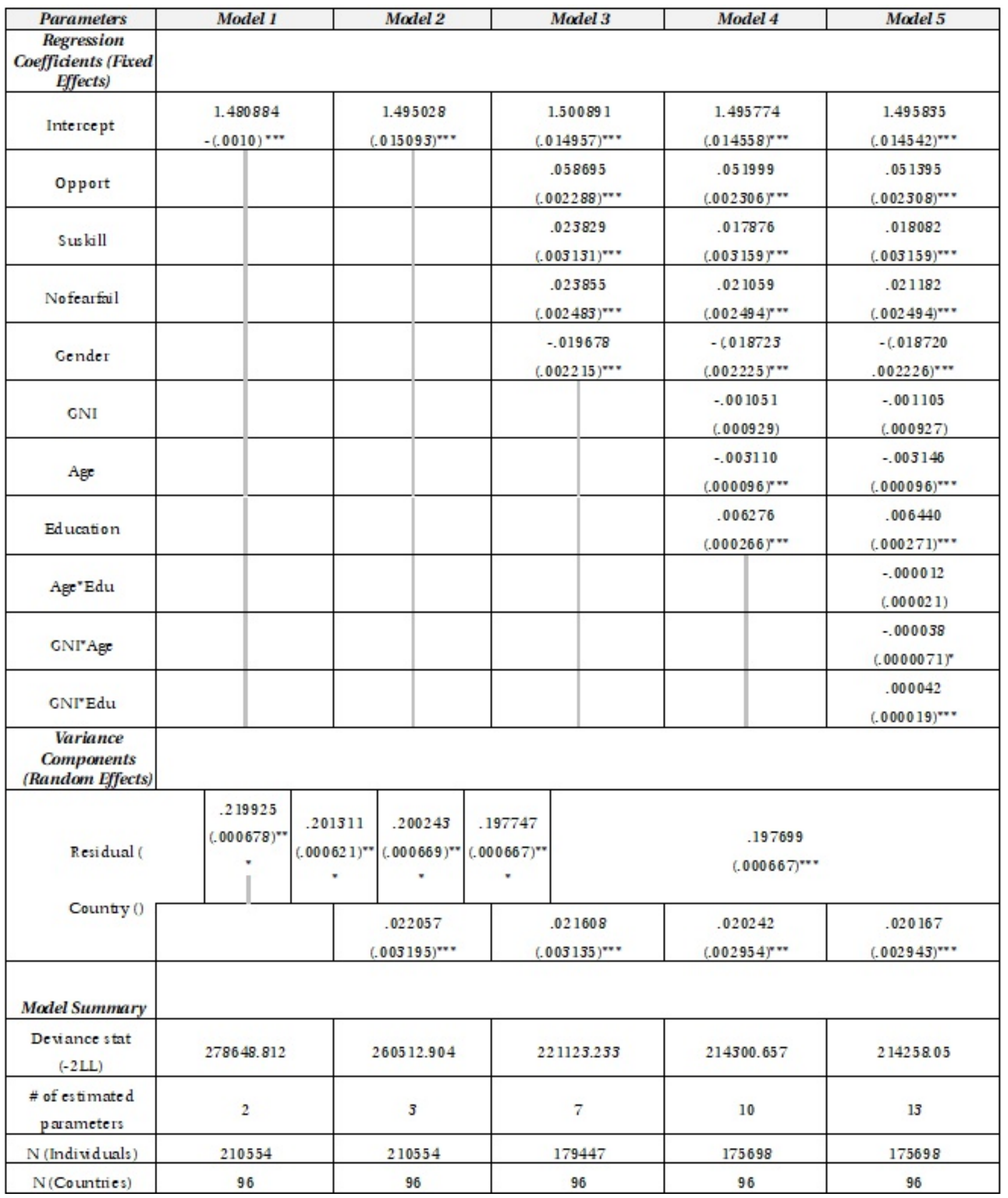




\section{Human Capital, Its Constituents, and Entrepreneurial Innovation}

\section{Vijay Vyas and Renuka Vyas}

\section{MLM with predictors}

Now we enter our centred predictors in MLM as per the equation below:

$\mathrm{I}=\gamma_{0}+\gamma_{\text {opport }}+\gamma_{\text {suskil }}+\gamma_{\text {nff }}+\gamma_{\text {gender }}+\gamma_{\text {age }}+\gamma_{\text {edu }}+$ $\gamma_{\mathrm{NI}}+\mu_{\mathrm{C}}+\varepsilon$

This brings into play age (education), and per capita national income as innovation influencing factors. The results of this model, summarized in Table 3, Model 4, show that fixed effects of all control variable as well as random effects of variable Country continue to be highly significant $(\mathrm{p}<0.001)$. They additionally show that age and education are significant predictors of innovation. As postulated, age has a negative effect and education has a positive effect. However, they also show that per capita gross national product (GNP) is not a significant predictor of entrepreneurial innovation. This means that $\mathrm{H} 1$ and $\mathrm{H} 2$ are supported $(\mathrm{p}<0.001)$. However, H3 is not supported.

\section{MLM with interaction variables}

Finally, we enter our interaction variables in the analysis as below:

$\mathrm{I}=\gamma_{0}+\gamma_{\text {opport }}+\gamma_{\text {suskil }}+\gamma_{\text {nff }}+\gamma_{\text {gender }}+\gamma_{\text {age }}+\gamma_{\text {edu }}+$ $\gamma_{\mathrm{NI}}+\gamma_{(\text {age } * \text { edu })}+\gamma_{(\mathrm{NI} \text { age })}+\gamma_{(\mathrm{NI} * \mathrm{edu})}+\mu_{\mathrm{C}}+\varepsilon$

The results of this model, summarized in Table 3, Model 5 , show that fixed effects of all control variables, that of predictors, age and education, as well as random effects of variable Country continue to be highly significant. They also show that per capita GNI negatively influences the relationship of age with innovation $(\mathrm{p}<$ 0.05 ) and it positively influences relationship of education with innovation $(\mathrm{p}<0.001)$, as postulated. However, it shows that age does not influence the relationship education of with innovation. This means that H3a $(\mathrm{p}<0.001)$ and H3b $(\mathrm{p}<0.05)$ are supported but $\mathrm{H} 2 \mathrm{a}$ is rejected.

\section{Local effect size}

To determine the magnitude of influence captured by MLM, we use the equation below:

( $\sigma^{2}$ null model - $\sigma^{2}$ Model 5) / ( $\sigma^{2}$ null model $)$

The Null model includes only the general intercept and no random effects, control variables, or predictors. The equation above therefore, captures the total effect size, which is $10 \%$.

To know what part of this $10 \%$ variance is explained by our predictors, we use the equation below: $\left(\left[\sigma^{2}\right.\right.$ Model $3+\tau^{2}$ Model 3] $-\left[\sigma^{2}\right.$ Model $5+\tau^{2}$ Model 5$\left.]\right) /$ $\left(\left[\sigma^{2}\right.\right.$ Model $3+\tau^{2}$ Model 3])

This shows that $2 \%$ out of the total $10 \%$ variance in innovation is accounted for by the predictors.

\section{Model fit}

To check the improvements in model fit at successive stages of analysis, we compare -2 log likelihood (-2LL) ratios where smaller values are indicative of better fit of the model to the data. Subtracting -2LL deviance of Model 2 from that of Model 1, we find a positive difference of $+18136(\mathrm{p}<0.001)$, indicating a better fit of Model 2 than Model 1. The difference in -2LL between Model 3 and Model 2 is +39390 , between Model 4 and Model 3 it is +6823 , and between Model 5 and Model 4 it is +43 . This means that, at each stage of analysis, the fitness of data to the model has improved.

\section{Discussion and Conclusions}

We discover that, at the individual level, being young and recently educated are significant predictors of entrepreneur innovation whereas, at the societal level, national wealth dampens the negative effect of age on innovation and heightens the positive effect of education on it. Our work, thus, extends the literature on the relationship between age and innovation by showing that younger entrepreneurs are more innovative and, by controlling for education, it establishes that this result is not as influenced by education as thought previously (Frosch, 2011).

We also find empirical support for our earlier argument that the cause of failure of previous research to extend human capital theory to innovation (Delgado-Verde et al., 2016; Marvel \& Lumpkin, 2007) is due to the inclusion of experience as a measure of human capital. Our work clarifies that it is only knowledge reflected in education -and not experience, echoed by age -that positively influences innovation. This finding is consistent with a significant part of previous research (Colombo et al., 2017; Crespo \& Crespo, 2016; Miguelez et al., 2011; Rupietta \& Backes-Gellner, 2017; Teixeira \& Fortuna, 2010).

Our interaction results show that, notwithstanding their relative higher average age, the ability of entrepreneurs in developed countries to utilize their education for innovation is enhanced by the wealth of their nations, and we argue that this "wealth effect" operates through the mechanism of differential quality of national innovation support systems (Albuquerque et al., 2015; Lundvall, 2008; Watkins et al., 2015). As a result, entrepreneurs in richer countries have better 


\section{Human Capital, Its Constituents, and Entrepreneurial Innovation}

\section{Vijay Vyas and Renuka Vyas}

innovation outcomes as national wealth accentuates the positive effect of education on innovation and dampens the negative effect of age on it.

\section{Limitations}

The variable age used in our work is chronological age, which " is best conceived as a proxy for true mechanistic changes that influence cognition across time" (MacDonald et al., 2011). As innovation needs "strong analytical thinkers", individuals with high cognitive ability (De Visser et al., 2014), chronological age only approximates the true changes that occur over time in an individual's ability to innovate. We have also posited linear relationships in our conceptual model. However, curvilinear effects of age (Jones, 2010) and national income on innovation are more plausible. The variable innovation in our analysis is not an objective measure but is computed from entrepreneurs' selfreported responses to innovation-related questions. Finally, MLM has its own set of limitations that affect all studies that use this procedure including this research (González-Romá \& Hernández, 2017). However, one specific limitation of MLM that affects studies with small datasets is not applicable in our case as both the number of groups (countries) and number of observations in each group are very large.

\section{Contributions}

We contribute to human capital theory by making a conceptual and empirical case against the use of work experience as a constituent of human capital. We explain the cause of counterintuitive and conflicting evidence in extant research on influence of human capital on innovation and suggest a path for its resolution. By using MLM, we contribute to the adoption of more robust methodological handling of GEM data. Using one of the largest available datasets, we carry out the first exploration of effect of entrepreneur age on innovation. We also theorize and test a novel set of moderating effects on innovation.

\section{Implications for practice and future research directions}

Given the disparities in educational provision between countries and the nexus among education, innovation, and economic prosperity, it is obvious from our findings that poorer countries should make investment in education their top priority. As demographic ageing has not yet set in, in these countries, this appears to be the straightest path to prosperity.

Though all developed countries perceive international students a key part of their intangible exports, not all allow them the opportunity to settle down. Adverse innovation implications of this policy are highlighted by this work. Its converse ramification for the less developed countries such as India and China, from where the largest number of international students originate, however, is that they are losing a potential source of innovation, their competitiveness, and future growth in this process, and they would gain by improving the quality of their educational delivery as well as by extending it.

We also hope that this work generates more conceptual debate and further research on composition of human capital. As this study is based on data that is predominantly of very small enterprises (Schøtt \& Jensen, 2016), studies using multi-country data of larger organizations should provide a complementary perspective to this scrutiny.

\section{References}

Albuquerque, E., Suzigan, W., Kruss, G., \& Lee, K. (Eds.). 2015. Developing National Systems of Innovation: University Industry Interactions in the Global South. Cheltenham, UK: Edward Elgar Publishing.

Al-Laham, A., Tzabbar, D., \& Amburgey, T. L. 2011. The Dynamics of Knowledge Stocks and Knowledge Flows: Innovation Consequences of Recruitment and Collaboration in Biotech. Industrial and Corporate Change, 20(2): 555-583.

https://doi.org/10.1093/icc/dtr001

Alsos, G. A, Ljunggren, E., \& Hytti, U. 2013. Gender and Innovation: State of the Art and a Research Agenda. International Journal of Gender \& Entrepreneurship, 5(3): 236-256.

https://doi.org/10.1108/IJGE-06-2013-0049

Amabile, T. M., \& Khaire, M. 2008. Your Organization Could Use a Bigger Dose of Creativity, Harvard Business Review, 86(10): 101-109.

Arntz, M., \& Gregory, T. 2014. What Old Stagers Could Teach Us? Examining Age Complementarities in Regional Innovation Systems. ZEW Discussion Paper No 14-050. Leipzig, Germany: ZEW - Leibniz Centre for European Economic Research. https://dx.doi.org/10.2139/ssrn.2475947

Arvanitis, S., \& Stucki, T. 2012. What Determines the Innovation Capability of Firm Founders? Industrial \& Corporate Change, 21(4): 1049-1084.

https://doi.org/10.1093/icc/dts003

Barro, R. J. 1991. Economic Growth in a Cross Section of Countries. The Quarterly Journal of Economics, 106(2): 407-443. https://doi.org/10.2307/293794310

Barro, R. J. 2015. Convergence and Modernisation. The Economic Journal, 125(585): 911-942. https://doi.org/10.1111/ecoj.12247

Belso-Martinez, J. A., Molina-Morales. F. X., \& Mas- 


\section{Human Capital, Its Constituents, and Entrepreneurial Innovation}

Vijay Vyas and Renuka Vyas

Verdu, F. 2013. Combining Effects of Internal Resources, Entrepreneur Characteristics and KIS on New Firms. Journal of Business Research, 66(10): 2079-2089.

https://doi.org/10.1016/j.jbusres.2013.02.034

Bonin, H. 2017. The Potential Economic Benefits of Education of Migrants in the EU. EENEE Analytical Report No. 31. Brussels: European Commission.

Cao, X., \& Im, J. 2018. Founder Human Capital and New Technology Venture R\&D Search Intensity: The Moderating Role of an Environmental Jolt. Small Business Economics, 50(3): 625-642.

https://doi.org/10.1007/s11187-017-9911-5

Carson, R. J., \& Beeson, C. M. L. 2013. Crossing Language Barriers: Using Crossed Random Effects Modelling in Psycholinguistics Research. Tutorials in Quantitative Methods for Psychology, 9(1): 25-41.

Castellacci, F., \& Miguel, J. 2013. The Dynamics of National Innovation Systems: A Panel Cointegration Analysis of the Coevolution between Innovative Capability and Absorptive Capacity. Research Policy, 42(3): 579-594.

https://doi.org/10.1016/j.respol.2012.10.006

Colombo, L., Dawid, H., Piva, M., \& Vivarelli, M. 2017. Does Easy Start-up Formation Hamper Incumbents' R\&D Investment? Small Business Economics, 49(3): 513-531.

https://doi.org/10.1007/s11187-017-9900-8

Crespo, N. F., \& Crespo, C. F. 2016. Global Innovation Index: Moving beyond the Absolute Value of Ranking with a Fuzzy-Set Analysis. Journal of Business Research, 69(11): 5265-5271.

https://doi.org/10.1016/j.jbusres.2016.04.123

Davidsson, P., \& Honig, B. 2003. The Role of Social and Human Capital among Nascent Entrepreneurs. Journal of Business Venturing, 18(3): 301-331. https://doi.org/10.1016/S0883-9026(02)00097-6

De Visser, M., Faems, D., Visscher, K., \& De WeerdNederhof, P. 2014. The Impact of Team Cognitive Styles on Performance of Radical and Incremental NPD Projects. Journal of Product Innovation Management, 31(6): 1167-1180.

https://doi.org/10.1111/jpim.12247

Delgado-Verde, M., Martín-de Castro, G., \& AmoresSalvadó, J. 2016. Intellectual Capital and Radical Innovation: Exploring the Quadratic Effects in Technology-Based Manufacturing Firms. Technovation, 54: 35-47. https://doi.org/10.1016/j.technovation.2016.02.002

Dimov, D. 2017. Towards a Qualitative Understanding of Human Capital in Entrepreneurship Research. International Journal of Entrepreneurial Behaviour \& Research, 23(2): 210-227.

https://doi.org/10.1108/IJEBR-01-2016-0016

Dutta, N., \& Sobel, R. S. 2018. Entrepreneurship and Human Capital: The Role of Financial Development. International Review of Economics \& Finance, 57(May 2017): 319-332.

https://doi.org/10.1016/j.iref.2018.01.020

Enders, C. K., \& Tofighi, D. 2007. Centering Predictor
Variables in Cross-Sectional Multilevel Models: A New Look at an Old Issue. Psychological Methods, 12(2): $121-138$.

https://doi.org/10.1037/1082-989X.12.2.121

Felsenstein, D. 2015. Factors Affecting Regional Productivity and Innovation in Israel: Some Empirical Evidence. Regional Studies, 49(9): 1457-1468.

https://doi.org/10.1080/00343404.2013.837871

Freeman, C. 1995. The 'National System of Innovation' in Historical Perspective. Cambridge Journal of Economics, March 1993: 5-24.

https://doi.org/10.1093/oxfordjournals.cje.a035309

Frosch, K., \& Tivig, T. 2007. Age, Human Capital and the Geography of Innovation. Thünen-Series of Applied Economic Theory, No. 71. Rostock, Germany: University of Rostock Institute of Economics.

Frosch, K. H. 2011. Workforce Age and Innovation: A Literature Survey. International Journal of Management Reviews, 13(4): 414-430.

https://doi.org/10.1111/j.1468-2370.2011.00298.x

Gailly, B. 2018. Navigating Innovation: How to Identify, Prioritize and Capture Opportunities for Strategic Success. Switzerland: Springer, Cham.

Gerschenkron, A. 1952. Economic Backwardness in Historical Perspective. In B. F. Hoselitz (Ed.), The Progress of Underdeveloped Areas. Chicago, IL: University of Chicago Press.

González-Romá, V., \& Hernández, A. 2017. Multilevel Modeling: Research-Based Lessons for Substantive Researchers. Annual Review of Organizational Psychology and Organizational Behavior, 4(1): $183-210$.

https://doi.org/10.1146/annurev-orgpsych-041015062407

Holbrook, J. A., \& Clayman, B. P. 2003. Research Funding: Key to Clusters. Ottawa: Canadian Foundation for Innovation.

Jones, B. F. 2010. Age and Great Invention. The Review of Economics \& Statistics, 92(1): 1-14. https://doi.org/ 10.1162/rest.2009.11724

Kanfer, R., \& Ackerman, P. L. 2004. Aging, Adult Development, and Work Motivation. Academy of Management Review, 29(3): 440-458.

https://doi.org/10.5465/AMR.2004.13670969

Kianto, A., Sáenz, J., \& Aramburu. N. 2017. KnowledgeBased Human Resource Management Practices, Intellectual Capital and Innovation. Journal of Business Research, 81: 11-20.

https://doi.org/10.1016/j.jbusres.2017.07.018

Kortum, S. S. 1997. Research, Patenting, and Technological Change. Econometrica: Journal of the Econometric Society, 65(6):1389-1419.

Leiponen, A. 2005. Skills and Innovation. International Journal of Industrial Organization, 23(5-6): 303-323. https://doi.org/10.1016/j.ijindorg.2005.03.005

Lévesque, M., \& Minniti, M. 2006. The Effect of Aging on Entrepreneurial Behavior. Journal of Business Venturing, 21(2): 177-194. 


\section{Human Capital, Its Constituents, and Entrepreneurial Innovation}

Vijay Vyas and Renuka Vyas

https://doi.org/10.1016/j.jbusvent.2005.04.003

Levie, J., \& Autio, E. 2008. A Theoretical Grounding and Test of the GEM Model. Small Business Economics, 31(3): 235-263.

https://doi.org/10.1007/s11187-008-9136-8

Levie, J., Autio, E., Access, Z., \& Hart, M. 2014. Global Entrepreneurship and Institutions: An Introduction. Small Business Economics, 42(3): 437-444.

https://doi.org/10.1007/s11187-013-9516-6

Lundvall, B.-A. 2008. Higher Education, Innovation, and Economic Development. In Annual World Bank Conference on Development Economics 2008, Regional: Higher Education and Development. Washington, DC: World Bank.

MacDonald, S. W. S., DeCarlo, C. A., \& Dixon, R. A. 2011. Linking Biological and Cognitive Aging: Toward Improving Characterizations of Developmental Time. The Journals of Gerontology Series B: Psychological Sciences and Social Sciences, 66B (Supplement 1): i59-i70.

https://doi.org/10.1093/geronb/gbr039

Marvel, M. R. \& Lumpkin, G. T. 2007. Technology Entrepreneurs' Human Capital and Its Effects on Innovation Radicalness. Entrepreneurship Theory \& Practice, 31(6): 807-829.

https://doi.org/10.1111/j.1540-6520.2007.00209.x

Marvel, M. R., Davis, J. L., \& Sproul, C. R. 2016. Human Capital and Entrepreneurship Research: A Critical Review and Future Directions. Entrepreneurship Theory \& Practice, 40(3): 599-626.

https://doi.org/10.1111/etap.12136

Mcguirk, H., Lenihan, H., \& Hart, M. 2015. Measuring the Impact of Innovative Human Capital on Small Firms' Propensity to Innovate. Research Policy, 44(4): 965-976.

https://doi.org/10.1016/j.respol.2014.11.008

Miguelez, E., Moreno, R., \& Artís, M. 2011. Does Social Capital Reinforce Technological Inputs in the Creation of Knowledge. Regional Studies, 45(8): 1019-1038.

https://doi.org/10.1080/00343400903241543

Mincer, J. 1974. Schooling, Experience, and Earnings. New York: Columbia University Press.

Nelson, R. R., \& Rosenberg, N. 1993. Technical Innovation and National Systems. In R. Nelson (Ed.), National Innovation Systems: A Comparative Analysis: 3-21. New York: Oxford University Press.

Ng, T. W. H., \& Feldman, D. C. 2013a. A Meta-Analysis of the Relationships of Age and Tenure with InnovationRelated Behaviour. Journal of Occupational \& Organizational Psychology, 86(4): 585-616. https://doi.org/10.1111/joop.12031

Ng, T. W. H., \& Feldman, D. C. 2013b. Age and Innovation-Related Behavior: The Joint Moderating Effects of Supervisor Undermining and Proactive Personality. Journal of Organizational Behavior, 34(5):

https://doi.org/10.1002/job

Ng, T. W. H., \& Feldman, D. C. 2008. The Relationship of
Age to Ten Dimensions of Job Performance. Journal of Applied Psychology, 93(2): 392-423.

https://doi.org/10.1037/0021-9010.93.2.392

Ostrom, E. \& Ahn, T.-K. 2009. The Meaning of Social Capital and Its Link to Collective Action. In G. T. Svendsen \& G. L. H. Svendsen (Eds.), Handbook of Social Capital: The Troika of Sociology, Political Science \& Economics: 17-35. Northampton, MA: Edward Elgar.

Ouimet, P., \& Zarutskie, R. 2011. Who Works for Startups? The Relation between Firm Age, Employee Age, and Growth. Working Paper 11-31. Cambridge, MA: Center for Economic Studies, US Census Bureau.

Pfeifer, C., \& Wagner, J. 2012. Is Innovative Firm Behavior Correlated with Age and Gender composition of the Workforce? Evidence from a New Type of Data for German Enterprises. IZA Discussion Paper No 7050. Born, Germany: IZA Institute of Labor Economics.

Reynolds, P., Bosma, N., Autio, E., Hunt, S., De Bono, I. Servais, N., Lopez-Garcia, P., \& Chin, N. 2005. Global Entrepreneurship Monitor: Data Collection Design and Implementation 1998-2003. Small Business Economics, 24(3): 205-231.

https://doi.org/10.1007/s11187-005-1980-1

Rodríguez-Pose, A., \& Crescenzi, R. 2008. Research and Development, Spillovers, Innovation Systems, \& the Genesis of Regional Growth in Europe. Regional Studies, 42(1): 51-67.

https://doi.org/10.1080/00343400701654186

Rupietta, C., \& Backes-Gellner, U. 2017. High Quality Workplace Training and Innovation in Highly Developed Countries (No. 0074). Zurich, Switzerland: University of Zurich, Department of Business Administration (IBW).

Schøtt, T., \& Jensen, K. W. 2016. Firms' Innovation Benefiting from Networking and Institutional Support: A Global Analysis of National and Firm Effects. Research Policy, 45(6): 1233-1246.

https://doi.org/10.1016/j.respol.2016.03.006

Schubert, T., \& Andersson, M. 2015. Old Is Gold? The Effects of Employee Age on Innovation and the Moderating Effects of Employment Turnover. Economics of Innovation \& New Technology, 24(1-z): 95- 113 .

https://doi.org/10.1080/10438599.2014.897858

Schultz, T. W. 1960. Capital Formation by Education. Journal of Political Economy, 68(6): 571-583. https://www.jstor.org/stable/1829945

Schultz, T. W. 1961. Investment in Human Capital. The American Economic Review, 51(1): 177. https://www.jstor.org/stable/1818907

Simonton, D. K. 1988. Scientific Genius: A Psychology of Science. Cambridge, UK: Cambridge University Press:

Smith, A. 1952, Original 1776. An Inquiry into the Nature and Causes of the Wealth of Nations. In R. M. Hutchins \& M. J. Adler (Eds.), Great Books of the Western World: 39. Edinburgh: Encyclopaedia Britannica, Inc. 


\section{Human Capital, Its Constituents, and Entrepreneurial Innovation}

\section{Vijay Vyas and Renuka Vyas}

Subramaniam, M., \& Youndt, M. A. 2005. The Influence of Intellectual Capital on the Types of Innovative Capabilities. Academy of Management Journal, 48(3): 450-463.

https://doi.org/10.5465/amj.2005.17407911

Sweetland, S. R. 2018. Human Capital Theory: Foundations of a Field of Inquiry. Review of Educational Research, 66(3): 341-359. https://doi.org/ 10.2307/1170527

Teixeira, A. A. C., \& Fortuna, N. 2010. Human Capital, R $\&$ D, Trade, and Long-Run Productivity Testing the Technological Absorption Hypothesis for the Portuguese Economy, 1960 -2001. Research Policy, 39(3): 335-350.

https://doi.org/10.1016/j.respol.2010.01.009

UNDP. 2014. Human Development Report. New York: United Nations Development Programme.

Unger, J. M., Rauch, A., Frese, M., \& Rosenbusch, N. 2011. Human Capital and Entrepreneurial Success: A Meta-Analytical Review. Journal of Business Venturing, 26(3): 341-358.

https://doi.org/10.1016/j.jbusvent.2009.09.00

Vila, L. E., Perez, P. J., \& Morillas, F. G. 2012. Higher Education and the Development of Competencies for Innovation in the Workplace. Management Decision, 50(9): 1634-1648. https://doi.org/10.1108/00251741211266723

Watkins, A., Papaioannou, T., Mugwagwa, J., \& Kale, D. 2015. National Innovation Systems and the Intermediary Role of Industry Associations in Building Institutional Capacities for Innovation in Developing Countries: A Critical Review of the Literature. Research Policy, 44(8): 1407-1418. https://doi.org/10.1016/j.respol.2015.05.004

Wincent, J., Anokhin, S., \& Örtqvist, D. 2010. Does Network Board Capital Matter? A Study of Innovative Performance in Strategic SME Networks. Journal of Business Research, 63 (3): 265-275. https://doi.org/10.1016/j.jbusres.2009.03.012

Wright, P. M., \& McMahan, G. C. 2011. Exploring Human Capital: Putting 'Human' Back into Strategic Human Resource Management. Human Resource Management Journal, 21(2): 93-104. https://doi.org/10.1111/j.1748-8583.2010.00165.x

\section{About the Authors}

Vijay Vyas is Senior Lecturer in Entrepreneurship \& Enterprise at the Faculty of Business \& Law in University of Portsmouth in the United Kingdom. He holds a PhD from Edinburgh Napier University. He has been a Professor of Business Economics at the MS University in India and a visiting Professor in Entrepreneurship at Lancaster University in UK. He is the course director of MSc Innovation Management \& Entrepreneurship at University of Portsmouth.

Renuka Vyas is $\mathrm{PhD}$ Research Scholar at Cardiff University in the United Kingdom. She holds a master's degree in Social Research with a distinction from Birkbeck College, University of London, and a master's in Economics from MS University of Baroda in India. She has been a Senior Lecturer in Economics at a Gujarat University college and a visiting Faculty in Entrepreneurship \& Small Business Management at a Bhavnagar University Institute, both in India.

Citation: Vyas, V. \& R. Vyas. 2019. Human Capital, Its Constituents, and Entrepreneurial Innovation: A Multilevel Modelling of Global Entrepreneurship Monitor Data Technology Innovation Management Review, 9(8): 5-17. http://doi.org/10.22215/timreview/1257

Keywords: age, education, work experience, national income, human capital, innovation, multi-level 